\title{
PROPOSAL FOR A NEW CONCEPT OF NIGHT TRANSPORT IN URBAN TRANSPORT ŽILINA
}

\begin{abstract}
Night urban transport in Slovakia is realized by public transport only in selected regional cities. In the long run, due to the increasingly available taxi services and the lack of connection between rail transport and night public transport, it has a declining share in passenger transport. A new operation proposal is necessary for the regional city of Žilina, which considers not only the factor of continuity, but also other factors, such as economical operation and travel expenses. The main task of the article is therefore to propose a more usable concept that will attract as many satisfied passengers as possible to this segment of public transport.
\end{abstract}

Keywords: night urban transport, transfer time, Žilina town

\section{Tomáš Mihalik ${ }^{1}$}

${ }^{1}$ Faculty of Operation and Economics of Transport and Communications University of Žilina, Univerzitná 8215/1, 01026 Žilina; +421

Adrián Šperka

${ }^{2}$ University Science Park, University of Žilina, Univerzitná 8215/1, 01026 Žilina; +421/41 5137523

Karol Hrudkay ${ }^{2}$

${ }^{2}$ University Science Park, University of Žilina, Univerzitná 8215/1, 01026 Žilina; +421/41 5137524

\section{Introduction}

Night urban public transport is characterized as a public passenger transport service operated at night. This type of public transport is operated mainly by buses, but in some cities trams and trolleybuses are also used. The labeling of night routes may be different from the labeling of daytime routes. The letter $\mathrm{N}$ is usually used before the line number to indicate night routes. Some towns also have separate day and night tariffs (night fares are usually more expensive). Night lines are much more geographically limited, so they serve only selected important urban areas with a high population density. They are also characterized by a smaller number of connections (usually 30- or 60minute intervals) and different or longer routes than daily lines (Plyushteva \& Boussauw, 2020).

The main goal of this article is to design the transport service of the town of Žilina by night bus lines so that it primarily meets the criterion of connection to railway transport. This requirement stems from the preferences of rail transport, which is widely used mainly by pupils and students under the age of 26 and seniors over the age of 60 regarding free transport. Furthermore, the operationaleconomic criterion represented by vehicle kilometers will be considered. The aim of both selected criteria is to compare with the current situation. The subsequent proposal already takes these criteria into account as much as possible.

\section{Urban public transport in Slovakia}

The history of the first operation of public transport dates to the $19^{\text {th }}$ century, when the first horse-drawn trams appeared in Bratislava. The current state of urban public transport operations is described in Figure 1, where the individual operations are divided into day and night. it is common ground that every night operation also has day operation.
Number of night urban public transport operations

Number of daily urban public transport operations

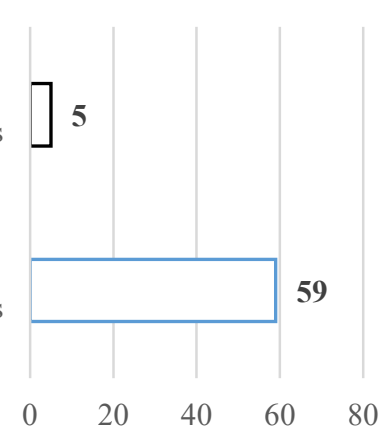

Fig. 1. Number of public transport operations in Slovakia (iMHD.sk, 2017)

Night urban public transport is operated in a total of five regional cities. The operating principles, the means of transport used as well as the number of lines are given in Table 1.

Table 1. The structure of urban public transport in Slovakia (iMHD.sk, 2017)

\begin{tabular}{|l|l|l|}
\hline Town & Number of lines & Type of vehicle \\
\hline Bratislava & 20 & buses and trolleybuses \\
\hline Košice & 7 & buses \\
\hline Prešov & 2 & buses and trolleybuses \\
\hline Trenčín & 1 & \multirow{2}{*}{ bus } \\
\hline Žilina & 1 & \\
\hline
\end{tabular}

It is clear from the table that most night city transport lines run in the capital. They are followed by Košice, as the second largest town. Night lines usually run from 23:00 to 04:30. In some towns, their operation starts earlier (around 22:30) and ends later (around 5:00).

It is important for the efficient functioning of night public transport that the setting of the timetable. This setting must be based on the bindings that each night line must have. They are shown in Figure 2. 


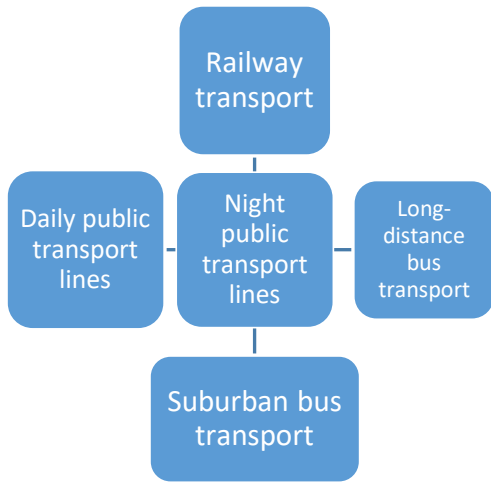

Fig. 2. Bindings between night transport and other modes of transport

If these bindings are secured in the timetable, the use of night lines by passengers is greater. If some bindings do not correspond to the smooth transfer of passengers between modes, their use is smaller and economically unsustainable in the long run.

\section{Current state of night public transport in Žilina}

The history of night public transport in Žilina dates to 1970, when the night line 50 was established. Its route began at the railway station and ended at university dormitories, because at that time students were the most numerous groups of passengers (Mihalik, 2021).

Line 50 has been running on the current route since 1 April 2009. In principle, only the departure times of the individual stops and the vehicles used changed. In the last 12 years, Žilina has not undergone such massive housing construction that it is necessary to adapt public transport lines (Mihalik, 2021). Currently, the line serves all important points in the city. The railway station, the hospital (only in the return direction), the university halls of residence Hliny and Vel'ký Diel and the housing estates Vlčince, Solinky and Hájik. The current timetable in direction Železničná stanica - Hájik is in Table 2.

Table 2. Timetable for night line 50 in the direction of Železničná stanica - Hájik valid from 1 April 2021 (Dopravný podnik mesta Žiliny, s. r. o., 2021)

\begin{tabular}{|l|c|c|c|c|}
\hline Stops & \multicolumn{4}{|l|}{} \\
\hline Železničná stanica & $\mathbf{2 2 : 5 5}$ & $\mathbf{0 : 0 5}$ & $\mathbf{1 : 2 0}$ & $\mathbf{3 : 0 0}$ \\
\hline Predmestská & $22: 57$ & $0: 07$ & $1: 22$ & $3: 02$ \\
\hline $\begin{array}{l}\text { Košická, TESCO } \\
\text { hypermarket }\end{array}$ & $22: 58$ & $0: 08$ & $1: 23$ & $3: 03$ \\
\hline Svätých Cyrila a Metoda & $23: 00$ & $0: 10$ & $1: 25$ & $3: 05$ \\
\hline Obchodná & $23: 01$ & $0: 11$ & $1: 26$ & $3: 06$ \\
\hline Matice slovenskej & $23: 02$ & $0: 12$ & $1: 27$ & $3: 07$ \\
\hline Fatranská & $23: 03$ & $0: 13$ & $1: 28$ & $3: 08$ \\
\hline Pod hájom & $23: 06$ & $0: 16$ & $1: 31$ & $3: 11$ \\
\hline Jaseňová & $23: 07$ & $0: 17$ & $1: 32$ & $3: 12$ \\
\hline Limbová & $23: 08$ & $0: 18$ & $1: 33$ & $3: 13$ \\
\hline Smreková & $23: 09$ & $0: 19$ & $1: 34$ & $3: 14$ \\
\hline Pol'ná & $23: 11$ & $0: 21$ & $1: 36$ & $3: 16$ \\
\hline Hlinská & $23: 12$ & $0: 22$ & $1: 37$ & $3: 17$ \\
\hline Mostná & $23: 13$ & $0: 23$ & $1: 38$ & $3: 18$ \\
\hline Polícia & $23: 15$ & $0: 25$ & $1: 40$ & $3: 20$ \\
\hline Hálkova & $23: 16$ & $0: 26$ & $1: 41$ & $3: 21$ \\
\hline Závodského & $23: 18$ & $0: 28$ & $1: 43$ & $3: 23$ \\
\hline & \multicolumn{3}{|c}{}
\end{tabular}

\begin{tabular}{|l|c|c|c|c|}
\hline Žitná & $23: 19$ & $0: 29$ & $1: 44$ & $3: 24$ \\
\hline Mateja Bela & $23: 21$ & $0: 31$ & $1: 46$ & $3: 26$ \\
\hline Slnečné námestie & $23: 22$ & $0: 32$ & $1: 47$ & $3: 27$ \\
\hline Stodolova & $\mathbf{2 3 : 2 3}$ & $\mathbf{0 : 3 3}$ & $\mathbf{1 : 4 8}$ & $\mathbf{3 : 2 8}$ \\
\hline
\end{tabular}

We can see from the table that the distribution of individual connections during the night is even. Each of the four connections has a travel time of 28 minutes. The omission of a hospital stop in this regard can be considered a shortcoming.

For the return direction Hájik - Železničná stanica, the current timetable is given in Table 3.

Table 3. Timetable for night line 50 in the direction of Hájik Železničná stanica valid from 1 April 2021 (Dopravný podnik mesta Žiliny, s. r. o., 2021)

\begin{tabular}{|l|c|c|c|c|c|}
\hline Stops & \multicolumn{4}{|l}{} & $\Omega$ \\
\hline Stodolova & $\mathbf{2 3 : 2 8}$ & $\mathbf{0 : 4 3}$ & $\mathbf{1 : 5 8}$ & $\mathbf{3 : 4 3}$ & \\
\hline Slnečné námestie & $23: 29$ & $0: 44$ & $1: 59$ & $3: 44$ & \\
\hline Mateja Bela & $23: 30$ & $0: 45$ & $2: 00$ & $3: 45$ & \\
\hline Hôrecká & $23: 32$ & $0: 47$ & $2: 02$ & $3: 47$ & \\
\hline Žitná & $23: 33$ & $0: 48$ & $2: 03$ & $3: 48$ & \\
\hline Závodského & $23: 34$ & $0: 49$ & $2: 04$ & $3: 49$ & \\
\hline Mostná & $23: 37$ & $0: 52$ & $2: 07$ & $3: 52$ & $\mathbf{4 : 2 2}$ \\
\hline Hlinská & $23: 38$ & $0: 53$ & $2: 08$ & $3: 53$ & $4: 23$ \\
\hline Pol'ná & $23: 39$ & $0: 54$ & $2: 09$ & $3: 54$ & $4: 24$ \\
\hline Smreková & $23: 41$ & $0: 56$ & $2: 11$ & $3: 56$ & $4: 26$ \\
\hline Limbová & $23: 42$ & $0: 57$ & $2: 12$ & $3: 57$ & $4: 27$ \\
\hline Jaseňová & $23: 43$ & $0: 58$ & $2: 13$ & $3: 58$ & $4: 28$ \\
\hline Pod hájom & $23: 44$ & $0: 59$ & $2: 14$ & $3: 59$ & $4: 29$ \\
\hline Fatranská & $23: 47$ & $1: 02$ & $2: 17$ & $4: 02$ & $4: 32$ \\
\hline Matice slovenskej & $23: 49$ & $1: 04$ & $2: 19$ & $4: 04$ & $4: 34$ \\
\hline Obchodná & $23: 50$ & $1: 05$ & $2: 20$ & $4: 05$ & $4: 35$ \\
\hline $\begin{array}{l}\text { Svätých Cyrila a } \\
\text { Metoda }\end{array}$ & $23: 51$ & $1: 06$ & $2: 21$ & $4: 06$ & $4: 36$ \\
\hline Poštová & $23: 52$ & $1: 07$ & $2: 22$ & $4: 07$ & $4: 37$ \\
\hline $\begin{array}{l}\text { Spanyolova, } \\
\text { nemocnica }\end{array}$ & $23: 54$ & $1: 09$ & $2: 24$ & $4: 09$ & $4: 39$ \\
\hline Železničná stanica & $\mathbf{2 3 : 5 7}$ & $\mathbf{1 : 1 2}$ & $\mathbf{2 : 2 7}$ & $\mathbf{4 : 1 2}$ & $\mathbf{4 : 4 2}$ \\
\hline
\end{tabular}

From the table we can see that the bus in the direction from the Hájik housing estate to the railway station will also serve the hospital. The journey in this direction takes a total of 29 minutes, which is a minute longer than in the opposite direction. On weekdays, the morning transport of workers is also strengthened by means of a connection with departure at 4:22 from the Mostná stop. According to the timetable, only one vehicle is deployed on the route throughout the night. All stops on the route are at the sign. The connection to the night public transport line from / to the train is an important indicator, especially in terms of passenger potential. To define the connection, it is necessary to characterize the temporal and spatial continuity of connections.

The time sequence of connections is such a sequence of arrivals and departures of various means of public passenger transport, which allows, about the time needed to make the transfer, to comfortably use the subsequent departing connection of the same or another type of transport to continue the journey (Pečený, 2000).

The spatial sequence of connections expresses the distance to be traveled from one means of transport to 
another by which the passenger intends to continue the journey, considering the level of barrier-free access (Pečený, 2000).

Table 4 shows the links between passenger trains and night line 50.

Table 4. Bonds night public transport and rail transport (Dopravný podnik mesta Žiliny, s. r. o., 2021) (Železnice Slovenskej republiky, 2020)

\begin{tabular}{|c|c|c|c|c|}
\hline $\begin{array}{l}\text { From the } \\
\text { direction }\end{array}$ & $\begin{array}{l}\text { Train } \\
\text { number } \\
\text { and } \\
\text { type }\end{array}$ & $\begin{array}{l}\text { Train } \\
\text { arrival }\end{array}$ & $\begin{array}{l}\text { Departure } \\
\text { of the } \\
\text { night line }\end{array}$ & $\begin{array}{l}\text { Time to } \\
\text { transfer }\end{array}$ \\
\hline Bratislava & RR 717 & $22: 37$ & $22: 55$ & $18 \mathrm{~min}$. \\
\hline Púchov & Os 3357 & $23: 25$ & \multirow{2}{*}{$0: 05$} & $40 \mathrm{~min}$ \\
\hline Košice & RR 766 & $23: 55$ & & $10 \mathrm{~min}$. \\
\hline Košice & RJ 1020 & $0: 32$ & \multirow[b]{2}{*}{$1: 20$} & $48 \mathrm{~min}$. \\
\hline Praha & $\begin{array}{l}\mathrm{LE} \\
1259\end{array}$ & 1:07 & & $13 \mathrm{~min}$. \\
\hline Humenné & EN 442 & $1: 26$ & \multirow{5}{*}{$3: 00$} & 94 min. \\
\hline Bratislava & R 615 & $1: 27$ & & $93 \mathrm{~min}$. \\
\hline Košice & $\begin{array}{l}\mathrm{LE} \\
1248\end{array}$ & $2: 34$ & & $26 \mathrm{~min}$ \\
\hline Praha & RJ 1021 & $2: 49$ & & $11 \mathrm{~min}$. \\
\hline Humenné & R 614 & $2: 58$ & & $2 \mathrm{~min}$. \\
\hline Praha & EN 443 & $4: 17$ & - & - \\
\hline
\end{tabular}

The distance of spatial accessibility between railway transport and public transport ranges from $50 \mathrm{~m}$ to $200 \mathrm{~m}$, depending on the platform at which the train ends/starts. The problem is with barrier-free accessibility, as line 50 starts and ends at the Železničná stanica stop on the other side of the street in the direction of Štefánikovo námestie. The underpass under the train station is not barrier-free. However, due to the upcoming reconstruction of the Žilina junction, which also includes the pre-station area of the Žilina station, this problem will be eliminated.

With time availability, let's assume that the passenger wants to wait a maximum of 15 minutes during the transfer and needs a minimum of 5 minutes to transfer. The primary reason for such thinking is the fact that the passenger ends the journey in the city, so he is not tolerant of a longer wait. If he must wait longer, he will call a taxi service or, in good weather conditions, he can use a shared bicycle. Out of the total number of eleven transfer connections for incoming trains and the departing night line bus, only three transfer connections meet the condition set by us.

Table 5 shows the opposite bonds, i. e. transfer night line - train.

Table 5. Bonds rail transport and night public transport (Dopravný podnik mesta Žiliny, s. r. o., 2021) (Železnice Slovenskej republiky, 2020)

\begin{tabular}{|l|l|l|l|l|}
\hline \multirow{2}{*}{$\begin{array}{l}\text { To } \\
\text { direction }\end{array}$} & $\begin{array}{l}\text { Train } \\
\text { number } \\
\text { and } \\
\text { type }\end{array}$ & $\begin{array}{l}\text { Train } \\
\text { departure }\end{array}$ & $\begin{array}{l}\text { Arrival } \\
\text { of the } \\
\text { night } \\
\text { line }\end{array}$ & $\begin{array}{l}\text { Time to } \\
\text { transfer }\end{array}$ \\
\hline Praha & RJ 1020 & $0: 44$ & \multirow{2}{*}{$23: 57$} & $47 \mathrm{~min}$. \\
\hline Košice & $\begin{array}{l}\text { LE } \\
\text { 1259 }\end{array}$ & $1: 08$ & $61 \mathrm{~min}$. \\
\hline Humenné & R 615 & $1: 31$ & \multirow{2}{*}{$1: 12$} & $19 \mathrm{~min}$. \\
\hline Praha & EN 442 & $1: 41$ & & $29 \mathrm{~min}$. \\
\hline
\end{tabular}

\begin{tabular}{|c|c|c|c|c|}
\hline & $\begin{array}{l}\mathrm{LE} \\
1248\end{array}$ & $2: 38$ & \multirow{3}{*}{$2: 27$} & $11 \mathrm{~min}$. \\
\hline Košice & RJ 1021 & $2: 50$ & & $23 \mathrm{~min}$. \\
\hline Bratislava & R 614 & $3: 07$ & & $40 \mathrm{~min}$. \\
\hline Košice & RR 765 & $4: 12$ & \multirow{3}{*}{$4: 12$} & 0 min. \\
\hline Bratislava & RR 702 & $4: 23$ & & $11 \mathrm{~min}$. \\
\hline Humenné & EN 443 & $4: 36$ & & $24 \mathrm{~min}$. \\
\hline
\end{tabular}

For these connections, the transfer time is set at 20 minutes from the arrival of the train and 5 minutes required to switch between getting off the bus and getting on the train. The first significance of such a step is that the passenger starts his journey at the railway station, ie tolerates more time to change. The second significance is that some night trains stay in Žilina for several tens of minutes. However, immediately after the arrival of the train, the passenger can board.

This applies to the following trains (Železnice Slovenskej republiky, 2020):

- RJ 1020 - arrival from the station Košice at 0:32

- EN 442 - arrival from the station Košice at 1:26,

- R 614 - arrival from the station Humenné at 2:58,

- EN 443 - arrival from the station Praha at 4:17.

From the above, we can see that long-distance rail transport was primarily investigated in providing transfers between trains and night buses.

However, regional passenger trains also leave the Žilina station during night bus, but they do not have such great potential primarily for the following shortcomings:

- Os 3500 (Žilina - Rajec) - after adjustment of the night line timetable, a pedestrian transfer between the Smreková and Žilina-Solinky stops is possible,

- Os 3302 (Žilina - Trenčín) - low potential due to nonadaptation of the timetable for staff rotation at the Continental plant in Púchov,

- Os 3902 (Žilina - Čadca) - low potential due to nonadaptation of the timetable for staff rotation at the INA Kysuce plant in Kysucké Nové Mesto.

In the case of the mentioned operational shortcomings, in the following section we will look at the indicator of an economic nature, vehicle kilometers.

Vehicle kilometer is a unit of measurement representing the movement of a vehicle over one kilometer. The distance to be considered is the distance run. It includes movements of empty vehicles. Units made up of a tractor and a semi-trailer or a lorry and a trailer are counted as one vehicle (European Environment Aency, 1997). In our case, it will be a burden on the infrastructure of the town of Žilina by a night public transport line. This indicator is calculated according to the relationship 1 per year.

$$
\begin{aligned}
& \text { Vehicle kilometer }=(\text { number of connection } * \\
& \text { distance }) * 365
\end{aligned}
$$

In Table 6, the calculations according to relation 1 are performed for all connections in both directions, including the inserted connection in the section Mostná - Železničná stanica. 
Table 6. Calculation of vehicle kilometers of line 50

\begin{tabular}{|l|l|l|l|}
\hline Route & Distance & $\begin{array}{l}\text { Number of } \\
\text { connections }\end{array}$ & The result \\
\hline $\begin{array}{l}\text { Železničná } \\
\text { stanica }- \\
\text { Hájik }\end{array}$ & $15.1 \mathrm{~km}$ & & $\begin{array}{l}22046 \\
\text { vehicle } \\
\text { kilometers/per } \\
\text { year }\end{array}$ \\
$\begin{array}{l}\text { Hájik - } \\
\text { Železničná } \\
\text { stanica }\end{array}$ & $14.4 \mathrm{~km}$ & 4 & $\begin{array}{l}21024 \\
\text { vehicle } \\
\text { kilometers/per } \\
\text { year }\end{array}$ \\
\hline $\begin{array}{l}\text { Mostná - } \\
\text { Železničná } \\
\text { stanica }\end{array}$ & $10.6 \mathrm{~km}$ & 1 & $\begin{array}{l}\text { 660.6 } \\
\text { vehicle } \\
\text { kilometers/per } \\
\text { year }\end{array}$ \\
\hline $\mathbf{\Sigma}$ & & & \multicolumn{3}{|l|}{$\mathbf{4 5 7 3 0 . 6}$ vehicle kilometers/per year } \\
\hline
\end{tabular}

For connections from the Železničná stanica to Hájik and back, the number of days for the whole year was calculated. With the inserted connection from Mostná to the Železničná stanica, only working days were expected, which is a total of 251 working days for 2021. When driving back from the Hájik housing estate, the number of vehicle kilometers per year is lower by $1,022 \mathrm{~km}$. This is due to the different shorter route.

\section{Proposal of a new night public transport line}

The proposal of a new line is based on two basic factors. First, it is necessary to streamline the route so that the travel time of passengers from individual housing estates is not artificially extended and other stops are included in the public transport system, which are not served by night transport today. Another equally important factor is the connection between night line connections and passenger trains. Therefore, in the new concept, two lines are proposed to eliminate these problems. Both lines pass through the city center and are proposal to form a complete circuit without the need to turn the bus in front of the train station (Mihalik, 2021).

Night line 50 is proposal to speed up the service of the Vlčince and Solinky housing estates, running in both directions through Vysokoškolákov and Vojtecha Spanyola streets, stopping at all stops on the route. According to the proposal, the night line in the center is traced clockwise. The route of line 50 is proposed as a roundabout with a final / initial stop at the Railway Station. Line 50 would leave from the Železničná stanica stop (trolleybus platform) in the direction of Vlčince (Mihalik, 2021). Table 7 shows the proposed timetable for line 50 .

Table 7. Proposed night bus timetable 50 (Mihalik, 2021).

\begin{tabular}{|l|c|c|c|c|c|c|c|}
\hline Stops & \multicolumn{7}{|c|}{$\mathbf{~}$} \\
\hline $\begin{array}{l}\text { Železničná } \\
\text { stanica }\end{array}$ & $\mathbf{2 2 : 5 0}$ & $\mathbf{2 3 : 4 0}$ & $\mathbf{0 : 4 0}$ & $\mathbf{1 : 3 5}$ & $\mathbf{2 : 2 0}$ & $\mathbf{3 : 2 5}$ & $\mathbf{4 : 3 0}$ \\
\hline $\begin{array}{l}\text { Štefánikovo } \\
\text { námestie }\end{array}$ & $22: 51$ & $23: 41$ & $0: 41$ & $1: 36$ & $2: 21$ & $3: 26$ & $4: 31$ \\
\hline $\begin{array}{l}\text { Spanyolova, } \\
\text { nemocnica }\end{array}$ & $22: 52$ & $23: 42$ & $0: 42$ & $1: 37$ & $2: 22$ & $3: 27$ & $4: 32$ \\
\hline $\begin{array}{l}\text { Vysokoškolákov, } \\
\text { plaváreň }\end{array}$ & $22: 54$ & $23: 44$ & $0: 44$ & $1: 39$ & $2: 24$ & $3: 29$ & $4: 34$ \\
\hline Poštová & $22: 55$ & $23: 45$ & $0: 45$ & $1: 40$ & $2: 25$ & $3: 30$ & $4: 35$ \\
\hline $\begin{array}{l}\text { Svätých Cyrila a } \\
\text { Metoda }\end{array}$ & $22: 57$ & $23: 47$ & $0: 47$ & $1: 42$ & $2: 27$ & $3: 32$ & $4: 37$ \\
\hline Obchodná & $22: 58$ & $23: 48$ & $0: 48$ & $1: 43$ & $2: 28$ & $3: 33$ & $4: 38$ \\
\hline
\end{tabular}

\begin{tabular}{|l|l|l|l|l|l|l|l|}
\hline $\begin{array}{l}\text { Matice } \\
\text { slovenskej }\end{array}$ & $22: 59$ & $23: 49$ & $0: 49$ & $1: 44$ & $2: 29$ & $3: 34$ & $4: 39$ \\
\hline Fatranská & $23: 01$ & $23: 51$ & $0: 51$ & $1: 46$ & $2: 31$ & $3: 36$ & $4: 41$ \\
\hline $\begin{array}{l}\text { Žilinská } \\
\text { univerzita }\end{array}$ & $23: 03$ & $23: 53$ & $0: 53$ & $1: 48$ & $2: 33$ & $3: 38$ & $4: 43$ \\
\hline Pod hájom & $23: 04$ & $23: 54$ & $0: 54$ & $1: 49$ & $2: 34$ & $3: 39$ & $4: 44$ \\
\hline Jaseňová & $23: 05$ & $23: 55$ & $0: 55$ & $1: 50$ & $2: 35$ & $3: 40$ & $4: 45$ \\
\hline Limobvá & $23: 06$ & $23: 56$ & $0: 56$ & $1: 51$ & $2: 36$ & $3: 41$ & $4: 46$ \\
\hline Smreková & $23: 07$ & $23: 57$ & $0: 57$ & $1: 52$ & $2: 37$ & $3: 42$ & $4: 47$ \\
\hline Centrálna & $23: 09$ & $23: 59$ & $0: 59$ & $1: 54$ & $2: 39$ & $3: 44$ & $4: 49$ \\
\hline Pod hájom & $23: 10$ & $0: 00$ & $1: 00$ & $1: 55$ & $2: 40$ & $3: 45$ & $4: 50$ \\
\hline $\begin{array}{l}\text { Žilinská } \\
\text { univerzita }\end{array}$ & $23: 11$ & $0: 01$ & $1: 01$ & $1: 56$ & $2: 41$ & $3: 46$ & $4: 51$ \\
\hline Fatranská & $23: 13$ & $0: 03$ & $1: 03$ & $1: 58$ & $2: 43$ & $3: 48$ & $4: 53$ \\
\hline $\begin{array}{l}\text { Matice } \\
\text { slovenskej }\end{array}$ & $23: 14$ & $0: 04$ & $1: 04$ & $1: 59$ & $2: 44$ & $3: 49$ & $4: 54$ \\
\hline Obchodná & $23: 16$ & $0: 06$ & $1: 06$ & $2: 01$ & $2: 46$ & $3: 51$ & $4: 56$ \\
\hline $\begin{array}{l}\text { Svätých Cyrila a } \\
\text { Metoda }\end{array}$ & $23: 17$ & $0: 07$ & $1: 07$ & $2: 02$ & $2: 47$ & $3: 52$ & $4: 57$ \\
\hline $\begin{array}{l}\text { Košická, TESCO } \\
\text { hypermarket }\end{array}$ & $\Uparrow$ & $\Uparrow$ & $\Uparrow$ & $\Uparrow$ & $\Uparrow$ & $\Uparrow$ & $\mathbf{5 : 0 0}$ \\
\hline Poštová & $23: 18$ & $0: 08$ & $1: 08$ & $2: 03$ & $2: 48$ & $3: 53$ & \\
\hline $\begin{array}{l}\text { Vysokoškolákov, } \\
\text { plaváreň }\end{array}$ & $23: 20$ & $0: 10$ & $1: 10$ & $2: 05$ & $2: 50$ & $3: 55$ & \\
\hline $\begin{array}{l}\text { Spanyolova, } \\
\text { nemocnica }\end{array}$ & $23: 21$ & $0: 11$ & $1: 11$ & $2: 06$ & $2: 51$ & $3: 56$ & \\
\hline $\begin{array}{l}\text { Velká Okružná, } \\
\text { AUPARK }\end{array}$ & $23: 22$ & $0: 12$ & $1: 12$ & $2: 07$ & $2: 52$ & $3: 57$ & \\
\hline Polícia & $23: 24$ & $0: 14$ & $1: 14$ & $2: 09$ & $2: 54$ & $3: 59$ & \\
\hline Hurbanova & $23: 26$ & $0: 16$ & $1: 16$ & $2: 11$ & $2: 56$ & $4: 01$ & \\
\hline $\begin{array}{l}\text { Železničná } \\
\text { stanica }\end{array}$ & $\mathbf{2 3 : 2 8}$ & $\mathbf{0 : 1 8}$ & $\mathbf{1 : 1 8}$ & $\mathbf{2 : 1 3}$ & $\mathbf{2 : 5 8}$ & $\mathbf{4 : 0 3}$ & \\
\hline
\end{tabular}

The proposal includes a total of 6 connections on the entire circular route and the seventh connection is a commuter connection to the Košická garage, as the carriage of the night line falls under this garage. At the same time, this connection is also advantageous for the employees of the TESCO department store. The whole circuit takes a total of 38 minutes by bus. The advantage is also the connection at the Fatranská stop to the trolleybus line 4 from the last commuter connection, so that the connection to the trains at the railway station will be ensured by means of one transfer.

The concept of night line 51 is designed with an emphasis on the service of smaller town districts (Hliny, Bánová, Závodie and Hájik housing estates). This night line would also stop at all stops on its route. Opposite to line 50, it would be routed counterclockwise in the center. Line 51 would leave the platform in front of the station building in the direction of Hurbanova. Table 8 proposes a timetable for night line 51.

Table 8. Proposed night bus timetable 51 (Mihalik, 2021).

\begin{tabular}{|l|c|c|c|c|c|c|c|}
\hline Stops & \multicolumn{7}{|c|}{} \\
\hline Železničná stanica & $\mathbf{2 2 : 5 0}$ & $\mathbf{2 3 : 4 0}$ & $\mathbf{0 : 4 0}$ & $\mathbf{1 : 3 5}$ & $\mathbf{2 : 2 0}$ & $\mathbf{3 : 2 5}$ & $\mathbf{4 : 3 0}$ \\
\hline Hurbanova & $22: 52$ & $23: 42$ & $0: 42$ & $1: 37$ & $2: 22$ & $3: 27$ & $4: 32$ \\
\hline Polícia & $22: 54$ & $23: 44$ & $0: 44$ & $1: 39$ & $2: 24$ & $3: 29$ & $4: 34$ \\
\hline Komenského & $22: 55$ & $23: 45$ & $0: 45$ & $1: 40$ & $2: 25$ & $3: 30$ & $4: 35$ \\
\hline Mostní & $22: 56$ & $23: 46$ & $0: 46$ & $1: 41$ & $2: 26$ & $3: 31$ & $4: 36$ \\
\hline Hlinská & $22: 57$ & $23: 47$ & $0: 47$ & $1: 42$ & $2: 27$ & $3: 32$ & $4: 37$ \\
\hline Pol'ná & $22: 58$ & $23: 48$ & $0: 48$ & $1: 43$ & $2: 28$ & $3: 33$ & $4: 38$ \\
\hline $\begin{array}{l}\text { Kamenná, obchodné } \\
\text { centrum }\end{array}$ & $23: 01$ & $23: 51$ & $0: 51$ & $1: 46$ & $2: 31$ & $3: 36$ & $4: 41$ \\
\hline $\begin{array}{l}\text { Kamenná, domáce } \\
\text { potreby }\end{array}$ & $23: 02$ & $23: 52$ & $0: 52$ & $1: 47$ & $2: 32$ & $3: 37$ & $4: 42$ \\
\hline $\begin{array}{l}\text { Námestie Svätého } \\
\text { Jána Bosca }\end{array}$ & $23: 04$ & $23: 54$ & $0: 54$ & $1: 49$ & $2: 34$ & $3: 39$ & $4: 44$ \\
\hline Oslobodenia & $23: 05$ & $23: 55$ & $0: 55$ & $1: 50$ & $2: 35$ & $3: 40$ & $4: 45$ \\
\hline Jedl'ová & $23: 06$ & $23: 56$ & $0: 56$ & $1: 51$ & $2: 36$ & $3: 41$ & $4: 46$ \\
\hline Žitná & $23: 07$ & $23: 57$ & $0: 57$ & $1: 52$ & $2: 37$ & $3: 42$ & $4: 47$ \\
\hline Závodského & $23: 08$ & $23: 58$ & $0: 58$ & $1: 53$ & $2: 38$ & $3: 43$ & $4: 48$ \\
\hline Krížna & $23: 09$ & $23: 59$ & $0: 59$ & $1: 54$ & $2: 39$ & $3: 44$ & $4: 49$ \\
\hline Pod vinicou & $23: 10$ & $0: 00$ & $1: 00$ & $1: 55$ & $2: 40$ & $3: 45$ & $4: 50$ \\
\hline Stodolova & $23: 13$ & $0: 03$ & $1: 03$ & $1: 58$ & $2: 43$ & $3: 48$ & $4: 53$ \\
\hline Slnečné námestie & $23: 14$ & $0: 04$ & $1: 04$ & $1: 59$ & $2: 44$ & $3: 49$ & $4: 54$ \\
\hline
\end{tabular}




\begin{tabular}{|l|c|c|c|c|c|c|c|}
\hline Mateja Bela & $23: 15$ & $0: 05$ & $1: 05$ & $2: 00$ & $2: 45$ & $3: 50$ & $4: 55$ \\
\hline Hôrecká & $23: 18$ & $0: 08$ & $1: 08$ & $2: 03$ & $2: 48$ & $3: 53$ & $4: 58$ \\
\hline Bánovecká cesta & $23: 19$ & $0: 09$ & $1: 09$ & $2: 04$ & $2: 49$ & $3: 54$ & $4: 59$ \\
\hline Pol'ná & $23: 21$ & $0: 11$ & $1: 11$ & $2: 06$ & $2: 51$ & $3: 56$ & $5: 01$ \\
\hline Hlinská & $23: 22$ & $0: 12$ & $1: 12$ & $2: 07$ & $2: 52$ & $3: 57$ & $5: 02$ \\
\hline Bernolákova & $\Uparrow$ & $\Uparrow$ & $\Uparrow$ & $\Uparrow$ & $\Uparrow$ & $\Uparrow$ & $5: 03$ \\
\hline Nemocničná & $\Uparrow$ & $\Uparrow$ & $\Uparrow$ & $\Uparrow$ & $\Uparrow$ & $\Uparrow$ & $5: 05$ \\
\hline $\begin{array}{l}\text { Košická, TESCO } \\
\text { hypermarket }\end{array}$ & $\Uparrow$ & $\Uparrow$ & $\Uparrow$ & $\Uparrow$ & $\Uparrow$ & $\Uparrow$ & $\mathbf{5}: 07$ \\
\hline Mostná & $23: 23$ & $0: 13$ & $1: 13$ & $2: 08$ & $2: 53$ & $3: 58$ & \\
\hline $\begin{array}{l}\text { Vel'ká Okružná, } \\
\text { AUPARK }\end{array}$ & $23: 25$ & $0: 15$ & $1: 15$ & $2: 10$ & $2: 55$ & $4: 00$ & \\
\hline Štefánikovo námestie & $23: 27$ & $0: 17$ & $1: 17$ & $2: 12$ & $2: 57$ & $4: 02$ & \\
\hline Železničná stanica & $\mathbf{2 3 : 2 9}$ & $\mathbf{0 : 1 9}$ & $\mathbf{1 : 1 9}$ & $\mathbf{2 : 1 4}$ & $\mathbf{2 : 5 9}$ & $\mathbf{4 : 0 4}$ & \\
\hline
\end{tabular}

Also in this proposal, there are a total of 6 connections running the entire route and the seventh connection ends at the Košická, Tesco hypermarket stop. The ride takes a total of 39 minutes, and one bus is planned on the line. At the Hlinská stop, it is possible to change from the last seventh connection to trolleybus line 4.

Table 9 shows the newly created transfer times between the proposed night lines and passenger trains according to the current timetable.

Table 9. Transfer times between passenger trains according to the current timetable and the proposed night lines 50 and 51

\begin{tabular}{|c|c|c|c|c|}
\hline $\begin{array}{l}\text { From the } \\
\text { direction }\end{array}$ & $\begin{array}{l}\text { Train } \\
\text { number } \\
\text { and } \\
\text { type }\end{array}$ & $\begin{array}{l}\text { Train } \\
\text { arrival }\end{array}$ & $\begin{array}{l}\text { Departure } \\
\text { of the } \\
\text { night line }\end{array}$ & $\begin{array}{l}\text { Time to } \\
\text { transfer }\end{array}$ \\
\hline Bratislava & RR 717 & $22: 37$ & $22: 55$ & 13 min. \\
\hline Púchov & Os 3357 & $23: 25$ & $23: 40$ & $15 \mathrm{~min}$. \\
\hline Košice & RR 766 & $23: 55$ & \multirow{2}{*}{$0: 40$} & $45 \mathrm{~min}$. \\
\hline Košice & RJ 1020 & $0: 32$ & & $8 \mathrm{~min}$. \\
\hline Praha & $\begin{array}{l}\mathrm{LE} \\
1259\end{array}$ & $1: 07$ & \multirow{6}{*}{$1: 35$} & $28 \mathrm{~min}$. \\
\hline Humenné & EN 442 & $1: 26$ & & $9 \mathrm{~min}$. \\
\hline Bratislava & R 615 & $1: 27$ & & $8 \mathrm{~min}$. \\
\hline Košice & $\begin{array}{l}\text { LE } \\
1248 \\
\end{array}$ & $2: 34$ & & $51 \mathrm{~min}$. \\
\hline Praha & RJ 1021 & $2: 49$ & & $36 \mathrm{~min}$. \\
\hline Humenné & R 614 & $2: 58$ & & 27 min. \\
\hline Praha & EN 443 & $4: 17$ & $4: 30$ & $13 \mathrm{~min}$. \\
\hline
\end{tabular}

Transfer times have improved compared to the current situation and while maintaining the conditions set by us. The advantage is also that the lines leave the Železničná stanica stop at the same time. The formation of a transfer time between EN 443 and a night bus can also be assessed positively, as it has been missing so far.

Table 10 sets out the transfer times in reverse, ie night bus arrivals and train departures. Line 51 arrives at the Železničná stanica stop a minute later, so there will be twotime data in the arrival column in the table. First the arrival time of line 50 and then the arrival time of line 51 . The same will apply to the transfer time.

Table 10. Transfer times between the proposed night lines 50 and 51 and passenger trains according to the current timetable

\begin{tabular}{|l|l|l|l|l|}
\hline $\begin{array}{l}\text { From the } \\
\text { direction }\end{array}$ & $\begin{array}{l}\text { Train } \\
\text { number } \\
\text { and } \\
\text { type }\end{array}$ & $\begin{array}{l}\text { Train } \\
\text { arrival }\end{array}$ & $\begin{array}{l}\text { Departure } \\
\text { of the } \\
\text { night line }\end{array}$ & $\begin{array}{l}\text { Time to } \\
\text { transfer }\end{array}$ \\
\hline Praha & RJ 1020 & $0: 44$ & $0: 18 / 0: 19$ & $\begin{array}{l}26 \mathrm{~min} . / 25 \\
\text { min. }\end{array}$ \\
\hline
\end{tabular}

\begin{tabular}{|c|c|c|c|c|}
\hline Košice & $\begin{array}{l}\text { LE } \\
1259 \\
\end{array}$ & $1: 08$ & & $\begin{array}{l}50 \text { min. } / 49 \\
\text { min. }\end{array}$ \\
\hline Humenné & R 615 & $1: 31$ & \multirow{2}{*}{ 1:18/1:19 } & $\begin{array}{l}13 \mathrm{~min} . / 12 \\
\text { min. }\end{array}$ \\
\hline Praha & EN 442 & $1: 41$ & & $\begin{array}{l}23 \min . / 22 \\
\text { min. }\end{array}$ \\
\hline Praha & $\begin{array}{l}\text { LE } \\
1248 \\
\end{array}$ & $2: 38$ & \multirow{2}{*}{$2: 13 / 2: 14$} & $\begin{array}{l}25 \mathrm{~min} . / 24 \\
\mathrm{~min} .\end{array}$ \\
\hline Košice & RJ 1021 & $2: 50$ & & $\begin{array}{l}37 \text { min./36 } \\
\text { min. }\end{array}$ \\
\hline Bratislava & R 614 & $3: 07$ & $2: 58 / 2: 59$ & $9 \mathrm{~min} . / 8$ \\
\hline Košice & RR 765 & $4: 12$ & \multirow[b]{2}{*}{ 4:03/4:04 } & min. \\
\hline Bratislava & RR 702 & $4: 23$ & & $\begin{array}{l}20 \min . / 19 \\
\text { min. }\end{array}$ \\
\hline
\end{tabular}

Again, an improvement in transfer times can be stated based on the proposed operation of night public transport. It is clear from the table that the authors focused primarily on the preference for transfer times for national longdistance trains. This is mainly due to the good transfer times between these domestic trains and international connections in the capital town Bratislava and in Košice. It will be possible to change to the 3500 passenger train from Žilina to Rajec at the Smreková stop from line 50. The distance between the bus and the railway stop is $150 \mathrm{~m}$.

In Table 11, the calculations according to Equation 1 are performed for all connections in both directions, including the last commute connection to the Košická garages.

Table 11. Calculation of vehicle kilometers of the proposed night line service

\begin{tabular}{|c|c|c|c|}
\hline $\begin{array}{l}\text { Number of } \\
\text { night line }\end{array}$ & Distance & $\begin{array}{l}\text { Number of } \\
\text { connections }\end{array}$ & The result \\
\hline \multirow{2}{*}{50} & $\begin{array}{l}19.4 \mathrm{~km}- \\
\text { the whole } \\
\text { circuit }\end{array}$ & 6 & $\begin{array}{l}42486 \text { vehicle } \\
\text { kilometers/per } \\
\text { year }\end{array}$ \\
\hline & $\begin{array}{l}16.7 \mathrm{~km}- \\
\text { commute } \\
\text { night bus }\end{array}$ & 1 & $\begin{array}{l}6095.5 \text { vehicle } \\
\text { kilometers/per } \\
\text { year }\end{array}$ \\
\hline \multirow{2}{*}{51} & $\begin{array}{l}17.1 \mathrm{~km}- \\
\text { the whole } \\
\text { circuit }\end{array}$ & 6 & $\begin{array}{l}37449 \text { vehicle } \\
\text { kilometers/per } \\
\text { year }\end{array}$ \\
\hline & $\begin{array}{l}16.9 \mathrm{~km}- \\
\text { commute } \\
\text { night bus }\end{array}$ & 1 & $\begin{array}{l}6168.5 \text { vehicle } \\
\text { kilometers/per } \\
\text { year }\end{array}$ \\
\hline$\Sigma$ & \multicolumn{3}{|c|}{92199 vehicle kilometers/per year } \\
\hline
\end{tabular}

Due to the increase in the number of connections and the length of individual routes, the difference in this indicator compared to the current state is considerable. After percentage conversion, the proposed outputs are increased by $101.61 \%$.

\section{Conclusion}

Public transport at night has experienced decline or stagnation in most places in recent years, resulting in the reduction or disruption of such passenger routes. Such is the case in the city of Žilina, where the stagnant operation of line 50 is caused by various unfavorable factors, including insufficient links between trains and the night line. 
Based on a better interconnection of these two modes of transport, the article was to streamline operations by proposing a new concept of night transport. Figure 3 shows a comparison of the state of vehicle kilometers before and after the proposed variant of night traffic.

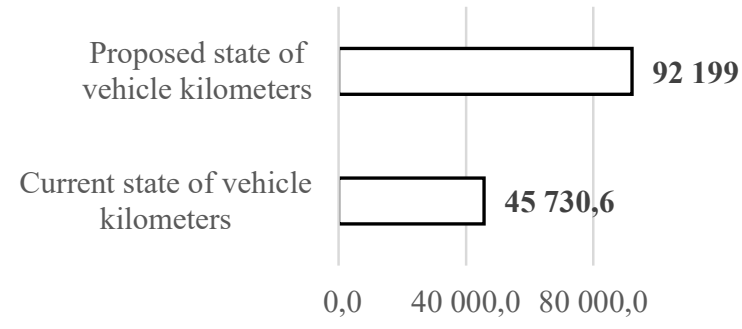

Fig. 3. Comparison of vehicle kilometers

At the same time, it was pointed out the possibility of introducing a new line that would serve those parts of the city that are not currently connected to the night public transport network. All this was evaluated by means of the vehicle kilometer indicator, which has not only operational but also economic significance.

\section{Acknowledgment}

"This publication was realized with support of Operational Program Integrated Infrastructure 2014 - 2020 of the project: Innovative Solutions for Propulsion, Power and Safety Components of Transport Vehicles, code ITMS 313011V334, co-financed by the European Regional Development Fund".

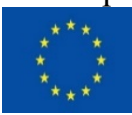

EUROPEAN UNION

European Regional Development Fund OP Integrated Infrastructure 2014 - 2020
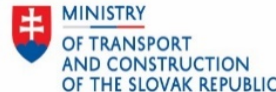
AND CONSTRUCTION
OF THE SLOVAK REPUBLIC

\section{References}

Dopravný podnik mesta Žiliny, s. r. o. (1. April 2021). Dopravný podnik mesta Žiliny. Dostupné na Internete: Cestovné poriadky vo formáte pdf platné od 1.4.2021: http://www.dpmz.sk/userfiles/Cestovn\%C3\%A9\%20poria $\mathrm{dky} /$ Cestovn\%C3\%BD\%20poriadok\%202021-04-01.pdf

European Environment Aency. (1. January 1997). Vehiclekilometre. Dostupné na Internete: European Environment Aency: https://www.eea.europa.eu/help/glossary/eeaglossary/vehicle-kilometre

iMHD.sk. (2017, January 1). MHD na Slovensku. Retrieved from imhd.sk: https://imhd.sk/transport/doc/sk/19364/19364

Lachnit, F. (27. 9 2005). Základní výpočty v silniční nákladní dopravě 1. Praha, Praha, Česká republika.

Mihalik, T. (8. January 2021). Téma: Nočné linky. Dostupné na Internete:

iMHD.sk: https://imhd.sk/za/doc/sk/20234/T\%C3\%A9maNo\%C4\%8Dn\%C3\%A9-linky.

Pečený, Z. (2000). Osobná doprava. Žilina: EDIS - vydavatel'ské centrum Žilinskej univerzity.

Plyushteva, A., \& Boussauw, K. (2020). Does night-time public transport contribute to inclusive night mobility? Exploring Sofia's night bus network from a gender perspective. Transport Policy, 41-50.
Železnice Slovenskej republiky. (2020). Cestovný poriadok vlakov osobnej dopravy 2020/2021. Bratislava: Železnice Slovenskej republiky. 